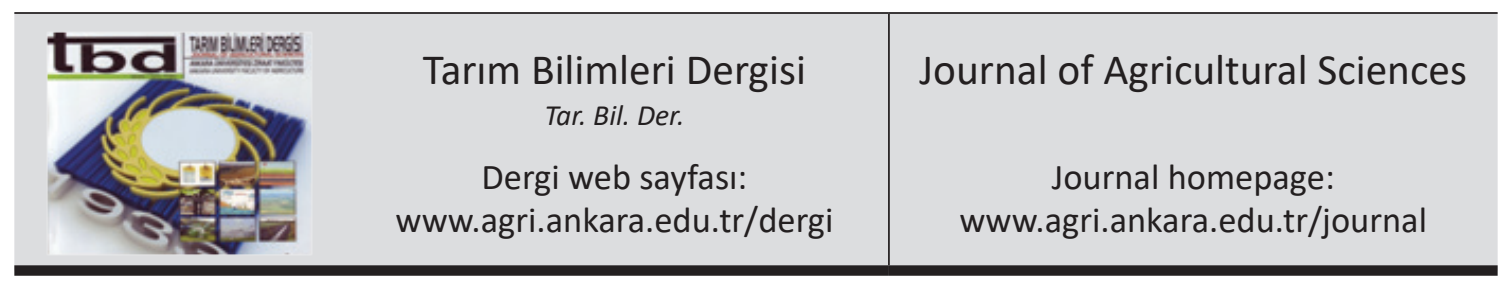

\title{
Investigation of the Temporal Variation of Water Quality in Ziyaret Pond Basin
}

\author{
İrfan OĞUZ ${ }^{\mathrm{a}}$, İsa KAYA ${ }^{\mathrm{b}}$, Rasim KOÇYİĞíT ${ }^{\mathrm{a}}$ \\ ${ }^{a}$ Gaziosmanpasa University, Agriculture Faculty, Department of Soil Science and Plant Nutrition, Tokat, TURKEY

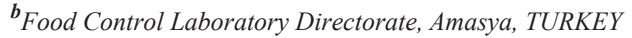

\section{ARTICLE INFO}

Research Article

DOI: 10.15832/ankutbd.380972

Corresponding Author: İrfan OĞUZ, E-mail: irfan.oguz@gop.edu.tr, Tel: +90 (356) 2521616

Received: 18 January 2018, Received in Revised Form: 14 May 2018, Accepted: 23 June 2018

\begin{abstract}
Urbanization, rapid population growth, intensive land use and land cover changes have negative impact on water quality. In this research, Amasya Ziyaret Pond's water basin flows' various physical and chemical specifications for 2014 water year (from 01 October 2013 to 29 September 2014) were studied. Temperature, pH, ammonium, nitrite, nitrate, potassium, sulphate, phosphorus, conductivity (EC) specifications of the basin pond flows were identified with the analysis of the water samples collected. Basin flows were estimated with the MIKE 11 NAM hydrological model. The variations between the instant flows values and parameters identified periodically in the research basin and the effect of basic management applications such as fertilization are identified. Eutrophication risk caused by phosphorus, nitrate, nitrite was identified.
\end{abstract}

Keywords: Surface water quality; Water pollution; Physical and chemical properties of waters; Ziyaret Pond

(C) Ankara Üniversitesi Ziraat Fakültesi

\section{Introduction}

Numerous issues such as industrialisation, population increase, rapid urbanization, improper land usage, climate change, excessive input use in agricultural production are central for the contemporary environmental problems, with detrimental effects on the sustainability of water resources.

A region's water quality and its water catchment basin's topography can be defined by evaluating the region's hydrogeology and hydrology together with the climate factors and human effects (Carpenter et al 1998; Jarvie et al 1998). In rural basins, surface waters are most susceptible to contamination since various pollutants such as fertilizers, pesticides, etc. are easily transported to streams, reservoirs and seas. Increasing intensity of agricultural activities and energy production based on water resources are fuelling the need for water (Graveline et al 2014; Bellin et al 2016). Intensive agricultural activities have also led to an increase in the use of pesticides and fertilizers and deterioration of surface water quality. While the applied nitrogenous fertilizers are directly transported, the phosphorous and potassium fertilizers can be carried away from the source together with the sediment. Rivers have the highest responsibility in hosting and transporting the pollutants (Ahmed et al 2011). 
Many human-induced effects are affecting pollution in water resources negatively. The solution of the problem may be possible by monitoring the seasonal variation of the pollution in rural basins for sustainable planning and the appropriate management of land and water resources. Several studies have been carried out in different regions for this purpose. In a study carried out, monitoring the water quality in Cinarli county of Hafik province in Sivas, monthly water samples were taken from six stations during 2011-2013, the river found to be exposed to pollutants and reported to be at risk (Mutlu et al 2016). As a result of a study conducted in China in four different basins and with five water quality parameters, the water quality was significantly different in settlement and nonsettlement areas. Water quality showed positive correlation with forestlands while presenting negative relation with impermeable and agricultural areas (Chen et al 2016).

In this research carried out in Amasya Ziyaret basin pond between 2013-2014, some chemical and physical properties of the basin flows were determined by the analysis of the instant water samples. The annual flow hydrograph of basin is combined with the measured water analysis values to determine the annual total chemical transport amount for the basin. The effects of basic soil management practices such as fertilization on basin are discussed. Water quality of the Amasya Ziyaret Pond, which was built for irrigation purposes, is tried to be determined according to water pollution control regulation (WPCR) and the possible negative effects of pollution elements on the irrigation area are investigated.

\section{Material and Methods}

\subsection{Research location}

Research was carried out in the Ziyaret Pond basin, located $4 \mathrm{~km}$ from the centre of Amasya province in Central Black Sea Region. Ziyaret Pond Basin is $28 \mathrm{~km}^{2}$ and its water source is Degirmendere. The amount of organic matter content in the basin soil is medium and $\mathrm{pH}$ is neutral or slightly alkaline.
The soil contains moderately lime and the $\mathrm{CaCO}_{3}$ content increases towards the sub soil surfaces (KHGM 1991). As the basin is located in the inner part of the Central Black Sea region, transition from the temperate climate of the coastal area to the harsh climate of the inner part is dominant. The average annual precipitation is $443 \mathrm{~mm}$ (DMI 2016). The catchment basin consists of agriculture, pasture and forest areas. Orchards, forage and field crops cultivating are carried out on the agricultural lands. The fertilization trends in farmland of the basin have been determined as a result of land surveys and interviews with farmers. Nitrogen, phosphorus and potassium composite fertilizers are applied to fruit trees in autumn, while potassium nitrate and calcium nitrate based fertilizers are applied in spring. Wheat, winter barley, rye and triticale are planted October, applying phosphor and first half nitrogen fertilizers, and second half of the nitrogen fertilizer in spring at tillering stage, in the basin.

\subsection{Water analysis}

Within the 2014 water year, 18 water samples with $250 \mathrm{~mL}$ sterile plastic containers were taken from a permanent measuring point established in the Degirmendere stream reaching the pond. Water samples were delivered to the laboratory promptly and analysed within 3 hours from the collection.

$\mathrm{pH}$, electrical conductivity (EC), ammonium, nitrite, nitrate, potassium, phosphorus and sulphate analyses were carried out for the water samples in the laboratory. EC measurements were realized by conductivity meter and $\mathrm{pH}$ measurements were performed with $\mathrm{pH}$ meter in the laboratory. Ammonium, nitrite, nitrate, potassium, phosphorus and sulphate contents were determined with suitable methods and test kits using DR5000 benchtop spectrometer (Hach-Lange Germany) (APHA 1998).

\subsection{Determination of annual transportation}

Basin flow data are needed to determine the annual total of various chemicals transported from the basin area. Since daily flows in the Basin were not measured, basin flows were estimated using the MIKE 11 NAM hydrological simulation model. 
MIKE11 NAM is a rainfall-runoff model developed by Danish Hydraulic Institute (DHI 2009). The model is deterministic, lumped and conceptual rainfall-runoff model that calculate overland flow, interflow and base flow.

In the study, the precipitation-flow section of the model was used and MIKE 11 NAM data entries were realised in 3 groups: installation parameters (parameters related to watershed area and soil properties), model parameters (time constants and drift for surface flow, threshold values for subsurface flow and base flow), meteorological data (daily precipitation and daily potential evaporation). The installation and parameters required by the model are obtained from soil and topographic maps and field studies, while the precipitation and evaporation data are obtained from Amasya Meteorological Station data.

\section{Results and Discussion}

\subsection{Some measured physical and chemical values of the Basin stream}

The highest water temperature of the basin flows was measured as $22.4{ }^{\circ} \mathrm{C}$ in August and the lowest $10{ }^{\circ} \mathrm{C}$ in January. It was observed that the temperature of the water decreased from October to January, and increased from January to August. From August onwards, the water temperature had the tendency to autumn decrease. The solubility of salts in water is generally directly proportional with the increase in temperature (Temponeras et al 2000). Therefore, it is envisaged that the solubility of the chemicals transported from the basin to the Ziyaret Pond between April and October will be higher and more effective. When the temperature values are compared with Water Pollution and Control Regulation (Anonymous 1988), the water reaching the pond was in first class water quality in terms of temperature.

The $\mathrm{pH}$ values of basin flows were measured throughout the water year. The $\mathrm{pH}$ value of the water feeding the pond did not change very much during the autumn and winter months (8.42-8.56) remaining low. However, the $\mathrm{pH}$ value (8.88-8.97) tended to increase in the spring months when the flows increased, reaching the highest $\mathrm{pH}$ value (9.78) in August. This rise in water $\mathrm{pH}$ measured in summer can be attributed to increased air circulation in the water and the photosynthesis of phytoplankton communities consuming $\mathrm{CO}_{2}$ present in the water. In winter, the declining trend of $\mathrm{pH}$ is due to the decrease in the flow and oxygen content, as well as the structure of the materials carried by the rain waters feeding the basin. The results of the study showing that the $\mathrm{pH}$ value is the lowest in November (6.79) and the highest in July (8.44) conducted by Alvarel-Rogel et al (2006) in Menor Lagoon in Spain, overlaps with the findings of the study we carried out in the basin. According to WPCR (2008), when evaluated in terms of $\mathrm{pH}$ value, the pond water quality was $2^{\text {nd }}$ class in December and February, $3^{\text {rd }}$ class in October, November, January, March, April, May and September while it was $4^{\text {th }}$ class in June, July and August. The measured EC values of the water samples ranged from $692 \mu \mathrm{S} \mathrm{cm}^{-1}$ to $1221 \mu \mathrm{S} \mathrm{cm}^{-1}$. The highest conductivity value was observed as $1221 \mu \mathrm{S} \mathrm{cm} \mathrm{cm}^{-1}$ in October and $692 \mu \mathrm{S}$ $\mathrm{cm}^{-1}$ at the lowest in July. Conductivity values were higher in autumn and winter compared to spring and summer months. Conductivity varies with concentration, mobility of existing ions present and water temperature (Garrison 1998). Higher stream flows in spring and summer months compared to autumn and winter months led to a decrease in EC values.

Ammonium was not detected in December, January and February at the Ziyaret Pond stream. The highest ammonium value was $0.284 \mathrm{mg} \mathrm{L}^{-1}$ in May. The ammonium values of the water feeding the pond increased from March, reaching the highest value $\left(0.293 \mathrm{mg} \mathrm{L}^{-1}\right)$ in May and began to fall again. Ammonium values showed a rapid increase in the spring months $\left(0.01-0.293 \mathrm{mg} \mathrm{L}^{-1}\right)$ and reached the highest value at the annual level. In winter months ammonium was not detected in the water, while in autumn months ammonium values observed to be close to each other (0.015-0.049 mg $\left.\mathrm{L}^{-1}\right)$. Lopes et al (2006) reported similar findings in 
a study they conducted in Portugal, Ria de Aveiro lagoon observing the highest $\mathrm{NH}_{4}^{+}$values during the summer months and lowest in the winter months. The increase in ammonium values from spring can be attributed to several causes such as; a) increased temperatures creating higher microbial activity causing increased organic material decomposition resulting the appearance of the ammonium, b) conversion of nitrate to ammonium by deoxidation event, and c) mixing of organic fertilizers used in agricultural land during the periods of rain and irrigation, to the stream by the surface and subsurface flows. The ammonium content of the Degirmendere stream feeding Ziyaret basin was $1^{\text {st }}$ class according to the WPCR (2008). In a study carried out by Odabasi \& Buyukates (2009) in Saricay river between $8^{\text {th }}$ July and $6^{\text {th }}$ August, the $\mathrm{NH}_{4}^{+}$values observed between $0.04-3.68 \mathrm{mg} \mathrm{L}^{-1}$. The $\mathrm{NH}_{4}^{+}$values of the Ziyaret Pond was found as 0.016 and $0.023 \mathrm{mg} \mathrm{L}^{-1}$ in July and August, respectively, which are lower than the $\mathrm{NH}_{4}^{+}$values obtained in the study conducted in Saricay river. Research carried out in the Lagoa de Araruama lake in Rio de Jenerio, Brazil, suggests that the ammonium content was in transition towards a eutrophic level (Souza et al 2003). Although the Ziyaret Pond ammonium content does not present a eutrophic hazard yet, it will be beneficial to consider the possibility of a transition towards eutrophic levels during rainy seasons, given that the study was conducted in an arid season.

The highest nitrite concentration was $0.73 \mathrm{mg} \mathrm{L}^{-1}$ in June and the lowest was $0.085 \mathrm{mg} \mathrm{L}^{-1}$ in March. The amount of nitrite feeding the pond started to increase $\left(0.053 \mathrm{mg} \mathrm{L}^{-1}\right)$ from March and a sharp decline was seen after June. Seasonally, the lowest nitrite concentration is in winter while the highest values are reached in spring and summer months. The basin stream's water is classified as $4^{\text {th }}$ class when the nitrite concentration is compared with the limit values of WPCR (2008). In a study carried out at Damsa Dam Lake, Mert et al (2010) identified the nitrite level within $3^{\text {rd }}$ class waters, according to WPCR (2008). It can be argued that Damsa Dam lake has a better water quality in terms of nitrite level.
Nitrite does not accumulate in the environment and is readily converted to nitrate since it is an intermediate product (Boyd 1990). However, in waters which nitrification is not sufficient, observing higher levels of nitrite is also possible (Secer 1997). Ziyaret Basin stream's nitrite concentration started to increase from the spring months. Increased leaching with increasing rainfall in the spring, the saturation of the soil and the decrease in $\mathrm{O}_{2}$ concentration in the water constitute anaerobic conditions. Consequently, nitrite concentration in the environment increases because it could not be sufficiently oxidized to nitrate. With the decrease in precipitation and temperatures, the nitrite concentration of the Ziyaret basin level has decreased.

The highest nitrate value of the Ziyaret Pond stream was found as $22.6 \mathrm{mg} \mathrm{L}^{-1}$ in February and the lowest nitrate concentration was $8.15 \mathrm{mg} \mathrm{L}^{-1}$ in August. Seasonally, nitrate concentration in the waters was partially increased in the spring, autumn and winter periods and reached its lowest level in summer. The fluctuations in nitrate concentration in the spring can be attributed to two factors. The first one is related with the nitrate fertilizers used in agricultural fields mixing into stream. The second one is the decrease in the $\mathrm{O}_{2}$ concentration of the water caused by the increase in precipitation and temperature, which further causes nitrite, insufficiently increasing to nitrate, transforming to nitrogen oxide under reducing conditions changing the nitrate concentration in the basin flows. Alvarez-Rogel et al (2006) reported an increase in nitrate concentration with the effect of agricultural areas around the lagoon, in their study of the Mar Menol lagoon in Spain. Ziyaret Pond stream's nitrate values varied between $2^{\text {nd }}$ and $4^{\text {th }}$ class water quality according to WPCR (2008). Protective measures are required to reduce the risk of nitrate-induced eutrophication in the pond.

The highest and lowest potassium value in the basin stream was found to be $26.6 \mathrm{mg} \mathrm{L}^{-1}$ in June and $0.22 \mathrm{mg} \mathrm{L}^{-1}$ in July, respectively. Potassium content was on the increase in spring months. 
Despite the highest potassium value measured in June, it showed a sharp decline in July.

It was observed that although the concentration of potassium in the water has risen from July, the potassium content of the water falls with the beginning of autumn. The highest determination of potassium value in summer is considered to be due to the application of commercial fertilizers with potassium content to agricultural areas in summer, especially to fruit gardens, mixing with water and reached to the pond.

The highest and lowest phosphorus value of basin stream is found as $0.916 \mathrm{mg} \mathrm{L}^{-1}$ in September and $0.186 \mathrm{mg} \mathrm{L}^{-1}$ in June, respectively. Phosphorus content showed a significant increase while it was lowest during summer. When the phosphorus values identified in the Ziyaret Pond Basin were compared with the WPCR (2008) values, the lowest and highest water quality were within the range of $3^{\text {rd }}$ class and $4^{\text {th }}$ class $\left(0.916 \mathrm{mg} \mathrm{L}^{-1}\right)$, when the lowest $\left(0.186 \mathrm{mg} \mathrm{L}^{-1}\right)$ and highest $\left(0.916 \mathrm{mg} \mathrm{L}^{-1}\right)$ values were taken into consideration, respectively. Souza et al (2003) observed in a study realised in Brazil that most of the changes in the inorganic phosphorus amount were due to human activities. Similarly, a significant part of the changes in phosphorus content reaching to Ziyaret Pond are due to commercial fertilizers applied by people to agricultural lands. In the autumn months, the amount of phosphorus started to increase as a result of the phosphoruscontaining commercial fertilizers mixing into the pond feeding water. The amount of phosphorus in the soil is reduced when the plants begin to absorb the phosphorus from the soil into the plants by spring. Thus, the amount of phosphorus reaching the pond through surface runoff and leaching was reduced. Furthermore, the decrease in the amount of adsorbed phosphorus transported to the pond with the sediment, due to low surface flows during the arid summer months is also effective in this reduction. Thus, it is observed that the amount of phosphorus in Degirmendere has started to fall rapidly from the last months of spring.
The highest and lowest sulphate values were observed as $25.2 \mathrm{mg} \mathrm{L}^{-1}$ in September and as 11.9 $\mathrm{mg} \mathrm{L}^{-1}$ in January, respectively. The sulphate concentration in the water continued to decline from October to January. The $\mathrm{SO}_{4}^{-2}$ amount in the water feeding the pond began to increase from winter to spring. The solubility of gypsum $\left(\mathrm{CaSO}_{4} \cdot 2 \mathrm{H}_{2} \mathrm{O}\right)$ in the soil increases with increasing temperatures. Gypsum with increased solubility, leached with the spring rainfall mixing to the water feeding the pond in the form of $\mathrm{SO}_{4}^{-2}$ caused this increase. According to WPCR (2008), the sulphate content of the Ziyaret Pond Basin is in the $1^{\text {st }}$ class water quality. Sen \& Golbasi (2014) in the study they carried out at Hazar Lake-Kurk Stream during the seven-month period when the Stream was in flow, found the average $\mathrm{SO}_{4}^{-2}$ value as $20.375 \mathrm{mg} \mathrm{L}^{-1}$. The $\mathrm{SO}_{4}^{-2}$ concentration of Ziyaret Pond was found to be $16.958 \mathrm{mg} \mathrm{L}^{-1}$ in 12 months period, which is lower than the study conducted in Kurk Stream.

\subsection{Seasonal and yearly total transport values to the pond with the basin stream}

In the scope of the study, some physical and chemical properties of surface water were determined with water samples taken from basin stream in 18 different periods in 2014 water year. The amount of flows in the basin must be known in order to be able to determine the annual total chemical transport reaching the pond. Basin flow amount should be known in order to identify the annual chemical transport reaching the basin.

Mike 11 Nam Hydrological model is used in the study to identify the daily flow amount of the basin. NAM is prepared with 9 parameters, representing surface zone, subsurface zone and ground water storage. Description of the model parameters for Degirmendere stream and their effects is presented in Table 1. The application of MIKE 11 model for rainfall runoff estimation was realized in two stages in the study. The first stage, in which the calibration process was realized to determine optimum values of the model parameters. In the second stage the streamflow was simulated the streamflow using the estimated model parameter during the calibration 
process. In the calibration procedure, several model parameters were adjusted by way of applying trial and error method to obtain optimum values. There were not daily flow records in the basin to optimize the model parameters and check the validity of the model estimation. In order to test the model success, the basin stream flows measured on five different dates; on $05^{\text {th }}$ and $29^{\text {th }}$ October $2013,09^{\text {th }}$ and $23^{\text {rd }}$ November 2013 and 23 $3^{\text {rd }}$ September 2014, were compared with the same day model prediction results for the same dates. Stream flows observed and simulated on five different occasions were presented as $0.00658 \mathrm{~m}^{3} \mathrm{~s}^{-1}-0.00022 \mathrm{~m}^{3} \mathrm{~s}^{-1} ; 0.00694$ $\mathrm{m}^{3} \mathrm{~s}^{-1}-0.00108 \mathrm{~m}^{3} \mathrm{~s}^{-1} ; 0.00704 \mathrm{~m}^{3} \mathrm{~s}^{-1}-0.00542$ $\mathrm{m}^{3} \mathrm{~s}^{-1} ; 0.00602 \mathrm{~m}^{3} \mathrm{~s}^{-1}-0.00458 \mathrm{~m}^{3} \mathrm{~s}^{-1} ; 0.00463 \mathrm{~m}^{3}$ $\mathrm{s}^{-1}-0.07599 \mathrm{~m}^{3} \mathrm{~s}^{-1}$ respectively. Observed and simulated flows were compared statistically by, two non-parametric approaches, called KolmogorovSmirnov and Shapiro Wilk, were applied to all of the observed and predicted data, for normality analysis. Their results showed that the full data set was not normally distributed. Therefore, the MannWhitney test was used to assess whether or not the two data sets (observed flows and predicted flows time series) obtain from the same population. The method implied that the median of them is not statistically different each other.

The flow hydrograph of 2014 water year predicted according to the annual simulation result realised with Mike 11 Nam model is given in Figure 1. According to the model estimates, daily basin flows showed a decrease in the autumn months, which was around $50 \mathrm{~L} \mathrm{~s}^{-1}$ in winter months, and increasing with the melting snow and precipitation received in spring, its highest estimated flow value of $383.4 \mathrm{~L} \mathrm{~s}^{-1}$, was on 30.04 .2014 . There are no periods without flow in the basin.

In order to calculate the total amount of ammonium, nitrite, nitrate, potassium, phosphorus and sulphate reached Ziyaret Pond annually, analysis results determined on the water samples' collection dates, are interpolated for the period between two measurement dates and converted to daily value comprising 365 days. To calculate the total daily chemical transportation, daily estimated water analysis results are multiplied by the flow amount

Table 1- Different parameters of the NAM model

\begin{tabular}{|c|c|c|}
\hline NAM parameter description & Effect & Parameter value \\
\hline Area of catchment, $\mathrm{km}^{2}$ & Volume of water yield & 28 \\
\hline $\begin{array}{l}\text { Maximum water content in surface storage } \\
\left(\mathrm{U}_{\max }\right), \mathrm{mm}\end{array}$ & $\begin{array}{l}\text { Overland flow, infiltration, evapotranspiration, } \\
\text { interflow }\end{array}$ & 10 \\
\hline $\begin{array}{l}\text { Maximum water content in root zone storage } \\
\left(\mathrm{L}_{\max }\right), \mathrm{mm}\end{array}$ & $\begin{array}{l}\text { Overland flow, infiltration, evapotranspiration, } \\
\text { base flow }\end{array}$ & 100 \\
\hline $\begin{array}{l}\text { Overland flow runoff coefficient }\left(\mathrm{C}_{\mathrm{QOF}}\right) \\
\text { dimensionless }\end{array}$ & Volume of overland flow and infiltration & 0.5 \\
\hline Time constant for interflow $\left(\mathrm{C}_{\mathrm{KIF}}\right)$, hours & Drainage of surface storage as interflow & 1000 \\
\hline $\begin{array}{l}\text { Root zone threshold value for overland flow } \\
\left(\mathrm{T}_{\mathrm{OF}}\right) \text {, dimensionless }\end{array}$ & $\begin{array}{l}\text { Soil moisture demand that must be satisfied for } \\
\text { overland flow to occur }\end{array}$ & 0.5 \\
\hline $\begin{array}{l}\text { Root zone threshold value for interflow }\left(\mathrm{T}_{\mathrm{IF}}\right) \text {, } \\
\text { dimensionless }\end{array}$ & $\begin{array}{l}\text { Soil moisture demand that must be satisfied for } \\
\text { interflow to occur }\end{array}$ & 0.5 \\
\hline $\begin{array}{l}\text { Groundwater recharge threshold (TG), } \\
\text { dimensionless }\end{array}$ & $\begin{array}{l}\text { Soil moisture demand that must be satisfied for } \\
\text { groundwater recharge to occur }\end{array}$ & 0 \\
\hline $\begin{array}{l}\text { Time constant for routing overland flow }\left(\mathrm{C}_{\mathrm{K} 1}\right) \text {, } \\
\text { hours }\end{array}$ & $\begin{array}{l}\text { Routing overland flow along catchment slopes } \\
\text { and channels }\end{array}$ & 10 \\
\hline Time constant for routing inter flow $\left(\mathrm{C}_{\mathrm{K} 2}\right)$, hours & Routing interflow along catchment slopes & 10 \\
\hline Timing constant for base flow $\left(\mathrm{C}_{\mathrm{KBF}}\right)$, hours & $\begin{array}{l}\text { Routing recharge through linear groundwater } \\
\text { recharge }\end{array}$ & 2000 \\
\hline
\end{tabular}




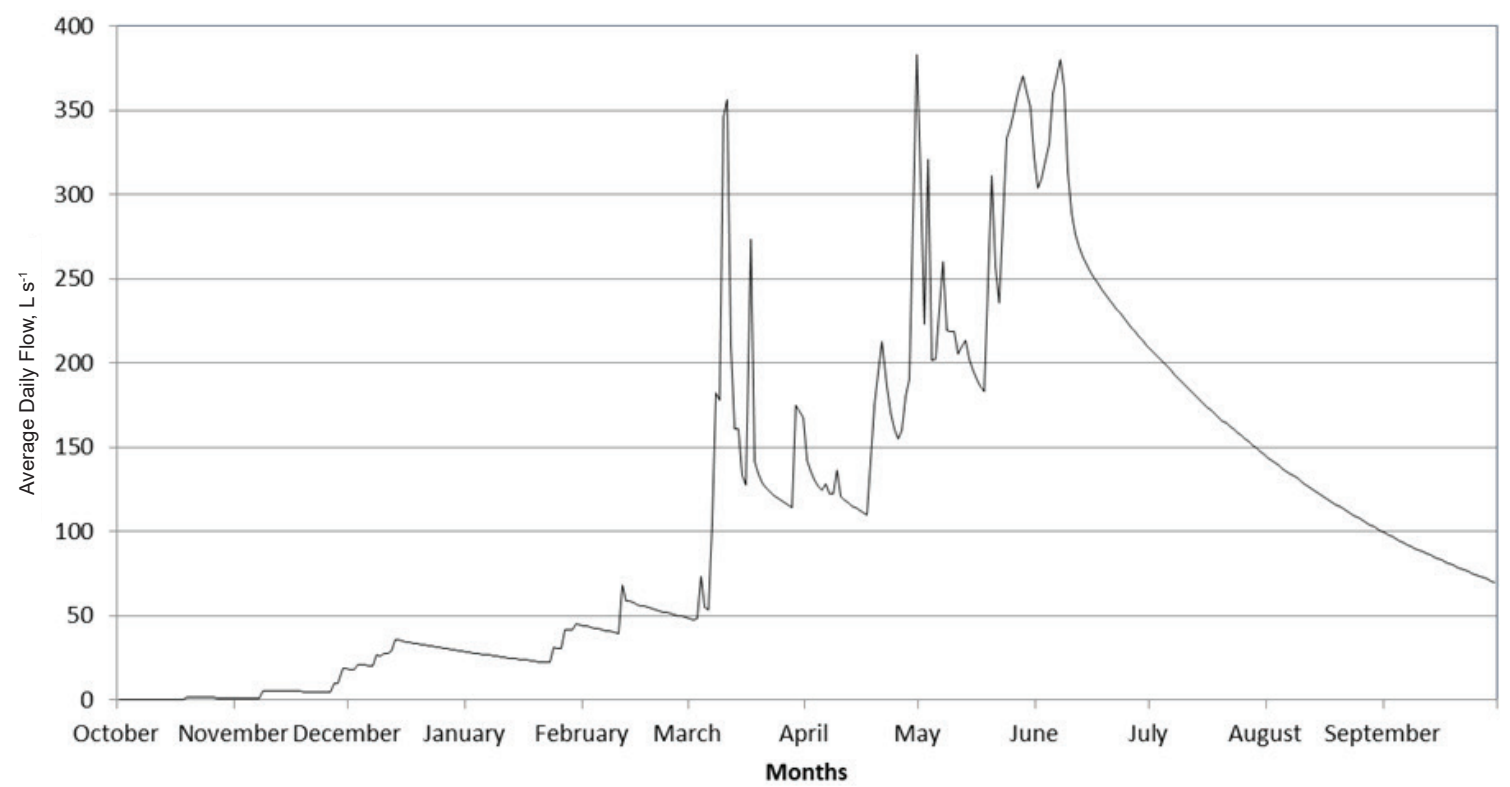

Figure 1- Ziyaret Pond basin 2014 water year hydrograph

and time. Total annual transport is determined by adding calculated daily values (Table 2 ).

Total ammonium, nitrite and nitrate nitrogen forms reaching the pond varied seasonally.
Ammonium is transported from high to low in the spring, summer, autumn and winter. Nitrite has been transported more during the spring and summer seasons, respectively, and has been transported in

Table 2- Monthly and seasonal transportation values for amonium, nitrit, nitrate, potassium, phosporus, sulphate (kg)

\begin{tabular}{|c|c|c|c|c|c|c|c|c|}
\hline \multirow{2}{*}{ Parameters } & \multicolumn{4}{|c|}{ Autumn } & \multicolumn{4}{|c|}{ Winter } \\
\hline & September & October & November & Total & December & January & February & Total \\
\hline Ammonium $\left(\mathrm{NH}_{4}^{+}\right)$ & 4.02 & 0.03 & 0.24 & 4.29 & 0.03 & 0.00 & 0.00 & 0.03 \\
\hline Nitrite $\left(\mathrm{NO}_{2}^{-}\right)$ & 19.59 & 0.20 & 1.46 & 21.25 & 7.73 & 5.28 & 7.98 & 20.99 \\
\hline Nitrate $\left(\mathrm{NO}_{3}^{-}\right)$ & 2556.75 & 28.29 & 255.85 & 2840.89 & 1557.96 & 1589.45 & 2718.53 & 5865.93 \\
\hline Potassium $\left(\mathrm{K}^{+}\right)$ & 2243.09 & 9.19 & 23.06 & 2275.35 & 71.40 & 56.49 & 103.74 & 231.63 \\
\hline Phosphorus $\left(\mathrm{P}_{2} \mathrm{O}_{5}\right)$ & 101.47 & 0.73 & 6.32 & 108.52 & 35.70 & 35.55 & 56.44 & 127.69 \\
\hline Sulphate $\left(\mathrm{SO}_{4}^{-2}\right)$ & 4924.66 & 29.23 & 226.83 & 5180.72 & 1006.46 & 921.79 & 1612.51 & 3540.76 \\
\hline \multirow{2}{*}{ Parameters } & \multicolumn{4}{|c|}{ Spring } & \multicolumn{4}{|c|}{ Summer } \\
\hline & March & April & May & Total & June & July & August & Total \\
\hline Ammonium $\left(\mathrm{NH}_{4}^{+}\right)$ & 9.93 & 52.43 & 339.39 & 401.75 & 180.95 & 7.42 & 7.13 & 195.50 \\
\hline Nitrite $\left(\mathrm{NO}_{2}^{-}\right)$ & 37.83 & 186.82 & 429.91 & 654.56 & 597.76 & 15.04 & 16.68 & 629.48 \\
\hline Nitrate $\left(\mathrm{NO}_{3}^{-}\right)$ & 6835.01 & 9339.58 & 22001.55 & 38176.14 & 15782.58 & 4875.15 & 2944.08 & 23601.81 \\
\hline Potassium $\left(\mathrm{K}^{+}\right)$ & 914.53 & 3888.96 & 10139.78 & 14943.27 & 21137.52 & 98.05 & 1936.31 & 23171.89 \\
\hline Phosphorus $\left(\mathrm{P}_{2} \mathrm{O}_{5}\right)$ & 187.26 & 259.04 & 560.73 & 1007.02 & 478.05 & 219.46 & 151.58 & 849.09 \\
\hline Sulphate $\left(\mathrm{SO}_{4}^{-2}\right)$ & 6495.51 & 11320.54 & 17507.47 & 35323.52 & 17526.01 & 7182.84 & 6123.84 & 30832.68 \\
\hline
\end{tabular}


close quantities in the autumn and winter months. Nitrate transport was mostly in spring and summer, followed by winter and autumn. Nitrate has been the most transported among the nitrogen forms followed by nitrite nitrogen. Nitrogen transport in the form of ammonium was less. It is estimated that the low transport soil in the form of ammonium is created with the effect of fixing ammonium nitrogen. The potassium transported to the pond with the surface waters occurred most in summer followed by spring months. While, increased surface flows with the snow melting during the spring months, are effective with the transportation of potassium, more potassium was transported in the summer months, when the flows were relatively low, due to more intensive use of potassium fertilizers applied to agricultural areas in the spring. Phosphorus transportation was observed during spring, summer, winter and autumn months, from high to low, respectively. Existing phosphorus transport is at a level creating eutrophication risk in the pond and precautions are required.

\section{Conclusions}

The water temperature values of Degirmendere have changed in parallel with the air temperature, however did not exceed quality water upper limit of $25{ }^{\circ} \mathrm{C}$. The $\mathrm{pH}$ values were strongly alkaline in October, November, December, January, February, March, April and May while very strongly alkaline in June, July, August and September. According to the "Water Pollution Regulation", the $\mathrm{pH}$ value of the water was $3^{\text {rd }}$ class in October, November, December, January, February, March, April and May, while it was $4^{\text {th }}$ class in June, July, August and September.

Particularly $\mathrm{SO}_{4}^{-2}$ has been transported $\left(74877.68 \mathrm{~kg}\right.$ year $\left.^{-1}\right)$ to Ziyaret Pond from its basin. $\mathrm{NO}_{2}^{-} 1326.28 \mathrm{~kg}$ year ${ }^{-1}, \mathrm{NO}_{3}^{-} 70484.78 \mathrm{~kg}$ year ${ }^{-1}$ and $\mathrm{NH}_{4}^{+} 601.57 \mathrm{~kg}$ year ${ }^{-1}$ reached the pond. The annual transport values of $\mathrm{K}^{+}$and $\mathrm{P}_{2} \mathrm{O}_{5}$ have been identified as $40622.14 \mathrm{~kg}_{\text {year }}{ }^{-1}, 2092.31 \mathrm{~kg}$ year $^{-1}$, respectively.

Degirmendere has $3^{\text {rd }}$ class water quality according to $\mathrm{K}^{+}, \mathrm{NH}_{4}^{+}$ve $\mathrm{SO}_{4}^{-2}$, and $4^{\text {th }}$ class water quality according to $\mathrm{NO}_{2}{ }^{-}$content.
According to the results of this research, it can be said that there is a risk of pollution and eutrophication for the pond in terms of $\mathrm{NO}_{2}^{-}$ content, the phosphorus content carries potential risk, and there is no significant pollution risk in terms of other chemical parameters discussed. In order to prevent water pollution in the pond and to sustain the ecological balance, it is recommended to take a holistic approach for the pollutants and pollution problem in the basin and at non-basin level. Sewerage network should be built in places where there is none in the basin. As the pond and its surroundings are used as a picnic area especially in the summer months, the amount of solid waste around the pond is increasing. For this reason, the solid wastes that accumulate around the pond should be gathered regularly as much as possible and people gathering for recreational purposes such as picnic should be informed about this. The use of fertilizers and pesticides in the basin should be taken under control. The amount and quality of the fertilizers used in agricultural areas should be determined according to the nutrient value of the soil, the plant species to be grown, while preventing excessive use of fertilizers.

\section{References}

Ahmed K, Das M, Islam M M, Akter M S, Islam S \& AlMansur M A (2011). Physico-chemical properties of tannery and textile effluents and surface water of river Buriganga and Karnatoli, Bangladesh. World Applied Sciences Journal 12(2): 152-159

Alvarez-Rogel J, Jimenez-Carceles F J \& Egea Nicolas C (2006). Phosphorus and nitrogen content in the water of a coastal wetland in The Mar Menor Lagoon (Se Spain): Relationships with effluents from urban and agricultural areas. Water, Air, and Soil Pollution 173: 21-38

Anonymous (1988). Su Kirliliği Kontrol Yönetmeliği. Resmi Gazete, 4 Eylül 1988, Say1: 19919

APHA (1998). Standard Methods for the Examination of Water and Wastewater. 20 $0^{\text {th }}$ Edition, American Public Health Association, Washington, DC

Bellin A, Majone B, Cainelli O, Alberici D \& Villa F (2016). A continuous coupled hydrological and 
water resources management model. Environmental Modelling Software 75: 176-192

Boyd C E (1990). Water quality in ponds for aquaculture. Alabama Agricultural Experiment Station, Auburn University, pp. 482

Carpenter S R, Caraco N F, Correll D L, Howarth R W, Sharpley A N \& Smith V H (1998). Nonpoint pollution of surface waters with phosphorus and nitrogen. Ecological Applications 8(3): 559-568

Chen X, Zhou W, Pickett S T A, Li W \& Han L (2016). Spatial-temporal variations of water quality and its relationship to land use and land cover in Beijing, China. International Journal of Environmental Research and Public Health 13(5): 449

DHI (2009). MIKE 11: A modeling system for rivers and channels. Reference manual. Danish Hydraulic Institute, Denmark

DMI (2016). Turkish State Meteorological Service records (Unpublished)

Garrison T (1998). Oceanography: an invitation to marine science $3^{\text {rd }}$ Ed.. Brooks/Cole-Wadsworth, USA

Graveline N, Majone B, Van Duiden R \& Ansink E (2014). Hydro-economic modeling of water scarcity under global change: an application to the Gallego river basin (Spain). Regional Environmental Change 14(1): 119-132

Jarvie H P, Whitton B A \& Neal C (1998). Nitrogen and Phosphorus in East Coast British Rivers: Speciation, sources and biological significance. Science of the Total Environment 210-211: 79-109

KHGM (1991). Amasya İli Arazi Varlığı. Köy Hizmetleri Genel Müdürlüğü, Etüd ve Proje Daire Başkanlığ 1 Yayınları, İl Rapor No: 05, Ankara, s. 16
Lopes J F, Dias J M, Cardoso A C \& Silva C I V (2006). The water quality of the Ria de Aveiro lagoon, Portugal: From the observations to the implementation of a numerical model. Marine Environmental Research 60(5): 594-628

Mert R, Bulut S, Yildirim G, Yilmaz M \& Gul A (2010). Damsa Baraj Gölü (Ürgüp) suyunun bazı fizikokimyasal parametrelerinin araştırılması. Gazi Üniversitesi Ĕgitim Fakültesi Dergisi 30(2): 285-302

Mutlu E, Kutlu B \& Demir T (2016). Assessment of Çinarli Stream (Hafik -Sivas)'s water quality via physicochemical methods. Turkish Journal of Agriculture Food Science and Technology 4(4): 267-278

Odabasi S \& Buyukates Y (2009). Çanakkale Sarıçay akarsuyu, klorofil- a çevresel parametreler ve besin elementlerinin günlük değişimleri. Ekoloji Dergisi 19(73): 76-85

Secer S (1997). Su toksikolojisi ders notları. Ankara Üniversitesi, Ziraat Fakültesi Su Ürünleri Bölümü (Unpublished), Ankara

Sen B \& Golbasi S (2014). Hazar Gölü'ne dökülen Kürk Çayı (Elazığg, Türkiye)'nda bitki besin ve katı madde miktarlarının mevsimsel değişimleri. Fırat Üniversitesi Fen Bilimleri Dergisi 26(2): 115-124

Souza M F L, Kjerfve B, Knoppers B, Souzaa W F L \& Damasceno R N (2003). Nutrient budgets and trophic state in a hypersaline coastal lagoon.: Lagoa de Araruama. Estuarine, Coastal and Shelf Science 57: 843-858

Temponeras M, Kristiansen J \& Moustaka M (2000). Seasonal variation in phytoplankton composition and physical chemical feactures of the Shallow Lake Doirani, Macedonia, Greece Hydrobiologia 424: 109122 